\title{
Public Justification, Inclusion, and Discursive Equality
}

THOMAS M. BESCH Wuhan University

ABSTRACT: The paper challenges the view that public justification sits well with emancipatory and egalitarian intuitions. I engage political liberalism's view of public justification. A standard objection to this view is that public justification should be more inclusive in scope. This is both plausible and problematic in emancipatory and egalitarian terms. If inclusive public justification allocates discursive standing that has much discursive purchase, as seems desirable in emancipatory terms, it is unable to allocate equal discursive standing within relevant scopes. And, if it must allocate equal discursive standing, discursive equality should be construed in terms that allow for unequal discursive purchase.

RÉSUMÉ : L'article questionne les supposés rapports entre justification publique et toute intuition émancipatrice et égalitaire. Je m'y confronte à l'idée de justification publique selon le libéralisme politique. On lui objecte que la justification publique devrait être plus inclusive. Ceci est tant plausible que problématique en termes émancipateurs et égalitaires. Si une justification publique inclusive alloue une posture ayant autant d'achat discursif que desire en terme d'émancipation, elle ne peut le faire au sein des domaines pertinents. Et, s'agit-il d'allouer une position discursive équivalente, l'égalité doit permettre un achat discursive inégal.

Keywords: public justification, reciprocity, respect, equality, political liberalism

\section{Introduction}

Robustly public justification - understood as a form of interpersonal justification by a standard of reciprocal, equal acceptability - is often taken to resonate especially well with basic emancipatory and egalitarian intuitions. Such justification

Dialogue 0 (2017), 1-24.

(C) Canadian Philosophical Association/Association canadienne de philosophie 2017 doi:10.1017/S0012217317000646 
1 aims to allocate to people a meaningful normative say in matters that affect 2 them (emancipation), and it aims to accord an equal normative say to equal 3 people (equality). This, it is sometimes said, is a key part of what it takes to 4 properly respect people's equal right to justification, their equal autonomy, 5 their equal dignity, or their freedom and equality. ${ }^{1}$ Accordingly, robustly public 6 justification aims to not impose on anyone whom it respects accordingly views or decisions they can relevantly reject. Given its emancipatory and egalitarian commitments, then, it aims to be inclusive in scope and non-dogmatic in its starting points, methods of reasoning, or conclusions.

Many have doubted that there can be a form of public justification that is emancipatory and egalitarian in the right way and that genuinely justifieswhile applying to the real world, outside ideal theory. ${ }^{2}$ While I side with the aspirations of non-ideal robustly public justification, I will here add to these doubts. I will identify two problems that call into question whether robustly public justification is well aligned with emancipatory and egalitarian intuitions. Prior to resolving these problems, I shall submit, there may not be a form of non-ideal robustly public justification that suitably coheres with basic emancipatory and egalitarian intuitions.

The first problem reflects the interdependence between the scope of public justification and what I call the 'purchase' of the discursive standing that such justification allocates. If this standing entails a strong normative say, or is rich in purchase - as would be desirable in light of emancipatory intuitions - then public justification may be unable to allocate such standing equally within a plausibly inclusive scope. But this runs up against egalitarian intuitions. The second problem reflects the complex nature of discursive equality in justificatory reciprocity. If public justification must allocate to people equal discursive standing - as many proponents of this kind of justification insist - the equality of that standing should be construed in terms that are purchase-sensitive (or so I shall suggest), but that nevertheless allow for purchase inequality. It is not clear what these terms are or how purchase inequality can sit with egalitarian intuitions. These are uneasy results for proponents of robustly public justification. ${ }^{3}$

My discussion proceeds as follows. Section 2 develops conceptual tools that I will use in discussing the two problems just referred to, including an account of dimensions of what I call 'discursive respect.' I then turn to a paradigm form

1 See Forst (2015a), (2015b), (2011), and (2007) esp. pp. 13-42, 209-211; Rawls (2001), (2005); Macedo (1991), chapter 2; Larmore (1990) and (2015).

2 Exemplary as a recent discussion of ideas of public justification is Enoch (2015). I will comment on Enoch below, in fn. 34.

3 I suppose throughout that it would be good if robustly public justification coheres with emancipatory and egalitarian intuitions and accords to people an equal meaningful say in relevant moral or political matters. This supposition is not uncontested: see Arneson (2004), esp. p. 46f; Steinhoff (2015). 
1 of public justification, i.e., the one advanced in Rawls-type political liberalism. 2 Section 3 identifies the kind of discursive standing that this kind of public jus3 tification accords to its fully enfranchised participants: it allocates a strong, 4 constitutive form of discursive standing that is deep in the order of justifica5 tion, rich in discursive purchase, yet notoriously limited in scope. In light of 6 emancipatory and egalitarian intuitions, a standard response here is to argue 7 that liberal public justification should be more inclusive in scope. But can there 8 be a duly non-dogmatic, inclusive form of robustly public justification that sits 9 well with emancipatory and egalitarian intuitions? This prompts my discussion 10 of the two above problems. I attend to the first problem in Section 4, and dis11 cuss the second problem in Section 5.

\section{Robustly Public Justification and Discursive Standing}

Let me start with a generic notion of robustly public justification. I will first consider publicness and then robustness.

Roughly, to say that $\varphi$ (e.g., a value judgement, principle, conception of justice, etc.) is justifiable 'publicly' is to say that $\varphi$ is authoritatively (e.g., reasonably, rationally, coherently) acceptable by relevant people (e.g., actual or possible people, affected others, fellow citizens). Alternatively, it is to say that $\varphi$ is justifiable by 'public' reasons, or reasons that are authoritatively acceptable by relevant people. This 'acceptability' standard can take many different forms. For example, there are positive and negative variants - we might require authoritative acceptability, or authoritative non-rejectability. And, if 'acceptability' is interpreted in thin modal terms, so as to count $\varphi$ as 'acceptable' by people when it is possible that they accept $\varphi$, the standard might amount to little more than an O'Neill-type followability requirement. ${ }^{4} \mathrm{Next}$, if the standard is applied only to $\varphi$, and not also to Betty's and Paul's reasons to accept $\varphi$, it is compatible with convergence requirements that allow $\varphi$ to count as publicly justifiable even if Betty and Paul cannot agree at the level of their reasons to accept $\varphi$. Alternatively, the standard might apply also at the level of Betty's and Paul's reasons to accept $\varphi$, but not also to their views as to why their respective reasons are good: this would allow for convergence at a deeper level of thought and argument. Not least, the standard can be applied at different levels of thought, argument, or decision making - as the example just provided already illustratesand it can be applied with varying scopes, or constituencies. For example, the standard might seek acceptability by all or only some affected actual people, or perhaps only by non-existent, ideal agents.

Less uncontested amongst theorists of public justification is robustness. I follow Gerald J. Postema's account of the notion. Robustness concerns the features through which robustly public justification confers on its conclusion whatever merit it confers on them. Robustly public justification takes it that the interpersonal

4 O’Neill (1996), pp. 51-59. 


\section{Dialogue}

1 authoritative acceptability of $\varphi$, or reasons to accept $\varphi$, confers, or is a key part of what confers, that merit - or that constitutes, or is a key part of what constitutes, $\varphi$ 's authority, validity, rightness, or reasonableness. ${ }^{5}$ This makes robustly public justification intersubjective at heart and constructivist in a weak, justificatory sense. ${ }^{6}$

Of course, not all conceptions of public justification are robustly public in this sense. For example, public justification is sometimes understood as public in an extremely thin, promulgatory sense as justification-in-public, or as a matter of laying out for others the reasons that, by the speaker's light, justify $\varphi$. Evidently, there is no implication here that these reasons, or their goodness, are subject to an interpersonal acceptability constraint. On a slightly more robust view, public justification is justification by reasons that are both good and subject to a (weak) publicity constraint. On one recent view, for instance, to justify $\varphi$ publicly is to justify $\varphi$ by a subset of good (or 'valid') reasons, namely, those good reasons that at the same time are such that relevant people could, at a relevant level of idealization, come around to grasping their goodness. ${ }^{7}$ This, too, does not entail that the interpersonal acceptability of these (allegedly) good reasons is what constitutes, or even contributes to, their goodness. Robustly public justification goes beyond these weak senses of the publicness of public justification. Stephen Macedo, a first-generation political liberal, aptly captures robust publicness:

At the most basic level, public justification has dual aims: it seeks reflective justification (good reasons) but it also seeks reasons that can be widely seen to be good by persons such as they are. (...) [B]y pursuing [these aims] together we respect not only the goodness of good reasons, but also the freedom and equality of citizens whose capacity for reason is limited and who espouse widely divergent comprehensive views. Indeed, the goodness of good reasons, for a public moral theory, becomes entirely a function of their capacity to gain widespread agreement among reasonable people moved by a desire for reasonable consensus. ${ }^{8}$

See Postema (1995a) and (1995b).

6 See Ronzoni (2010); Besch (2004), part I.

7 Steven Wall advances a form of public justification that construes its publicness along such lines: see Wall (2016). Kevin Vallier, too, advances a publicity view of publicness. Roughly, for Vallier, Betty is justified 'publicly' in believing $\varphi$ if she believes $\varphi$ on the basis of reasons that relevant other people can recognize as reasons that, from Betty's perspective, justify her believing $\varphi$. See Vallier (2015b), esp. p. 603f. See also Vallier (2011), and (2015a). Such views are not my primary concern here, although some of the problems I address below apply to them, too- - but this goes beyond what I can argue here.

8 Macedo (1991), p. 46f. See also Rawls (2005), esp. lecture III. Emphasis is mine. 
1 The last sentence makes the relevant point: robustly public justification is robustly 2 public in the sense that it takes the goodness of good reasons to entirely be a 3 function of their authoritative acceptability by relevant people. Arguably, first4 generation political liberals like Macedo, Charles Larmore, and John Rawls, 5 amongst others, take public justification to be robustly public in this sense.

Next, given its robustly public character, robustly public justification allocates a strong form of discursive standing to its fully enfranchised participants. To bring out what this standing is, let me assume that, where we are reasonable and others are concerned, we pursue at least two aims. First, we aim to act toward them on grounds, widely conceived, that are acceptable by them - that is, at least in principle, ideally, or given the (perhaps counterfactual) assumption that they look at things in the right way-thus, we accord them discursive standing. Second, however, we also aim to act toward them on grounds that, at least as far as we can tell, are good. This entails that reasonable people can accord others at least two kinds of discursive standing, depending on how they relate these two aims to one another. ${ }^{9}$

First, we might accord others derivative discursive standing. When we accord this standing, we aim to act toward others on grounds that are good and acceptable, but we take the acceptability of these grounds, or valuable forms of it, to derive from a proper appreciation of their goodness. Thus, we seek "ideal" unanimity (Thomas Nagel) or "normative" consent (David Estlund). ${ }^{10}$ Second, we might accord others a stronger, constitutive form of discursive standing. Where we accord others this standing - or, as I shall also say, were we accord them discursive respect - we aim to act on grounds that are good and acceptable, but we take the goodness of these reasons to (at least partly) depend on, or be constituted by, their acceptability. As the last passage quoted above reflects, Rawls-type public justification allocates to its fully enfranchised participants standing of this second, stronger kind.

We can describe conceptions of robust public justification as allocations of discursive respect: they prescribe that some form of constitutive discursive standing be allocated to each fully enfranchised participant, and lesser discursive standing, if any, to other people. As I argue in more detail elsewhere, allocation profiles of discursive respect can differ in various (interdependent, as we shall see later) dimensions, including what we might refer to as their 'scope,' 'depth,' and 'discursive purchase'-we might call this the 'matrix of discursive inclusion.' 11 The following provides a working notion of these three dimensions.

9 The discussion in this section follows the exposition of discursive respect and its dimensions in Besch (2014).

10 See Nagel (1991), p. 33f; Estlund (2008), p. 10.

11 For a specification of these dimensions and an account of their interdependence: see Besch (2014), and below. 
To begin with scope, we ask questions about scope when we ask questions such as: 'Who counts, or should count, as a fully enfranchised participant in public justification, or as a full member of its constituency?' or 'Who or what merits discursive respect?'. Questions about the scope of discursive are questions about the range of actual or possible others to whom we accord, or should accord, constitutive discursive standing. Next, take depth. We ask questions about the depth of discursive respect when we ask, e.g., how fundamental in the order of justification the things are that (allegedly) depend for their authority on their (qualified) acceptability by (some) other, actual or possible people. For example, are these first-order practical reasons only? Do they also include more fundamental, general moral or political principles? Is an acceptability requirement in some form applied even as a constitutive requirement of all practical reasoning, as some Kantian moral philosophers would have it? ${ }^{12}$

Especially relevant here is discursive purchase - an often-neglected dimension of discursive respect that is rarely recognized as a relevant dimension of such respect in its own right. Often, it seems, purchase is construed as a mere function of the degree in which justification standards idealize, while its importance is seen as secondary to the importance of identifying suitable levels of idealization. It is true that idealization and purchase are tied together. As I argue elsewhere, high degrees of idealization entail low degrees of purchase, and high degrees of purchase require low degrees of idealization; it does not follow, though, that purchase is systematically secondary to idealization. ${ }^{13}$ What we should take to be the systematic ordering between these things depends on the underlying aims of robust public justification - where some candidate aims favour high degrees of idealization, and others high degrees of purchase. But let me set this matter aside now, and treat purchase as a legitimate and relevant dimension of discursive respect. What I shall say suffices for my present purposes; for a more thorough picture, it is best seen in conjunction with what I say elsewhere. ${ }^{14}$

As I understand the notion, we consider the purchase of an agent's discursive standing when we consider what degree of normative influence in relevant justification practices this standing accords to that agent, given her actual deliberative resources, widely conceived (so as to include whatever views, volitions, skills, attitudes, capacities, and so on, she actually draws on in her practical reasoning). Purchase so construed is not a matter of the normative influence of non-actual, ideal agents in justification practices, nor is it a matter of the influence of actual agents with idealized resources. Instead, it is a matter of the normative influence of actual agents, given their actual deliberative resources,

12 For example, consider the status that Onora O'Neill accords to her "requirement of followability": see O'Neill (1988), p. 716f, and (2000), chapter 1.

13 See Besch (2017a).

14 See ibid.; Besch (2014). 
in relevant justification practices. In a sense, therefore, purchase helps to earth the normativity of justification: it helps to describe what normative distance there is, if any, between how actual agents actually go about their practical reasoning, and how they would have to go about their reasoning in order to do so in ways that relevant justification practices construe as authoritative. And, evidently, purchase is especially relevant in relation to emancipatory intuitionsassuming that emancipation (rightly or wrongly, for better or worse) requires that real people such as they are be accorded a meaningful level of normative influence in matters that affect them.

Discursive respect can take many forms that greatly vary in purchase. To see how, recall that such respect involves an aim of acting on 'acceptable' grounds. When is $\varphi$ 'acceptable'? Many modally different answers are possible. For example, consider:

(1) Paul accepts/does not reject $\varphi$.

(2) Paul is not committed to reject $\varphi$ in light of his actual views and volitions.

(3) Paul would not reject $\varphi$ in light of views and volitions he would/could have if he was ideally reasonable/rational (as we define this).

Evidently, the purchase that discursive respect can have for its recipients will vary greatly depending on what we take acceptability to require. Take two extreme examples. First, consider, say, actualist discursive respect-a conception of discursive respect that takes it that proper 'acceptability' requires something like (1) or (2). On such a conception, Betty's constitutive discursive standing can have a high degree of purchase. If Betty cannot now accept $\varphi$ coherently, given her actual views and volitions, this would count as showing that $\varphi$ is not suitably acceptable by her. This seems to give her a veto: her 'no,' it seems, counts for a 'no.' Contrast this with counterfactualizing discursive respect—or a conception of discursive respect that takes it that proper 'acceptability' requires something more like (3). On such a view, Betty's discursive standing can have very little purchase. That she cannot now accept $\varphi$ coherently, or is committed to oppose $\varphi$, might not count against $\varphi$ at all. For her rejection of $\varphi$ could be countered by the consideration that she would not reject $\varphi$ if she appreciated matters in a different, and, as others see it, more reasonable or rational light. Thus, Betty's actual views and volitions here might become irrelevant: her 'no' might not count for a 'no.'

Actualist discursive respect gives greatest normative weight to the actual views and volitions of people, or their actual deliberative resources. Once we start to normatively qualify, constrain, or launder these views and volitions, their impact decreases and a gap opens between the actual acceptability and the normative acceptability of our grounds. This gap widens as these qualifications become normatively more remote, or harder to meet, relative to people's actual views and volitions, or their actual deliberative resources. And, as it widens, the normative influence of their actual views and volitions decreases - and with 
1 this decreases the purchase of their discursive standing. Take again a coun2 terfactualizing view. My discursive respect for you can have fairly little sig3 nificance for you if you know that it allows me to take my reasons to be suitably volitions, could never actually accept them.

Two more remarks are in place. First, I index discursive purchase to an agent's actual deliberative resources. An alternative is to index it to the ideal resources of ideal agents, or the idealized resources of actual agents. As will emerge in Section 5, below, one reason to set aside these possibilities here is this: a focus on actual deliberative resources helps to keep in view potentially relevant forms of discursive inequality. Second, purchase and scope are linked: constraints on the scope of public justification can often be translated into purchase-determining qualifications of the sort of acceptability that public justification seeks (and vice versa). ${ }^{15}$ For example, if acceptability by reasonable people justifies, what justifies is reasonable acceptability. Still, we should not subsume purchase under scope (or vice versa). Purchase is useful in assessing in what way, if any, non-ideal public justification accords to people equal discursive standing (or so I claim). At any rate, it is relevant here as my focus is on views of public justification that, in one way or other, aim at a "basic structure of justification"16 that make questions of equality and emancipation, and with this of equal discursive purchase, relevant.

\section{Political Liberalism}

I now turn to Rawls's political liberalism, or one reading of the idea of public justification at its core. On this reading, which I call the 'deep view,' public justification has a special position in the matrix of discursive inclusion. On the deep view, public justification not only fully enfranchises actual reasonable people, given their actual reasonable deliberative resources; it also accords them discursive respect that is deep in political liberalism's order of justification, rich in discursive purchase, yet problematically limited in its scope of inclusion. I will not here try to defend or even fully lay out the deep view, as this would go beyond what can be done now-I do so elsewhere. ${ }^{17}$ Thus, I will employ it heuristically: it serves as one candidate view of the role of public justification in political liberalism that situates one of the longest-standing, recurrent concerns about the nature of that project. This is the concern that some of political liberalism's core commitments stand in need of a (public)

15 There are other ways in which scope and purchase are related. See Besch (2014), and below.

16 See Forst (2012), p. 262.

17 I develop the deep view as an account of Rawls's post-1985 views in Besch (1998) and (2004) - the latter also extends the deep view to Macedo's and Larmore's variants of political liberalism. See also Besch (2012), (2013), and (2017b). 
justification that political liberalism seems unable to itself provide ${ }^{18}$ - and this in a way that renders political liberalism vulnerable to a charge of public dogma (see below). What matters here is this problem (I shall later address challenges faced by attempts to respond to it). Readers who prefer a different reading of Rawls hence can set aside the specifics of the deep view, so long as they grant that political liberalism, on some relevant reading, faces a problem of that overall type. ${ }^{19}$

I start with the idea of a political liberalism. If a conception of justice, $\varphi$, is a political liberalism, $\varphi$ is liberal in content and political both in its form of justification and domain of application. If $\varphi$ is liberal in content, $\varphi$ allocates to citizens basic rights and liberties of special priority, as well as all-purpose means that help citizens to make use of these rights and liberties. If $\varphi$ is political in form of justification, it does two things. It (i) adopts the constructivist standard that reciprocal, equal acceptability by reasonable people justifies. And, importantly, (ii) it attaches a populist ${ }^{20}$ interpretation to that standard: that is, it interprets the standard such that $\varphi$ fails to meet the standard, or fails to qualify as reciprocally acceptable by reasonable people, already if $\varphi$ is the actual subject of reasonable disagreement between these people (where reasonable disagreement is defined as disagreement that can arise between reasonable people). ${ }^{21}$ (i) and (ii) are at the core of Rawls's political constructivism. And, for some political liberals, they are at the heart of an idea of political justification that fully respects reasonable people as free and equal. ${ }^{22}$ Not least, if $\varphi$ is political in its domain of application, $\varphi$ does two things. $\varphi$ regulates only the basic structure of a given society, or its most important social, political, and

18 For an early version of this concern: see Hampton (1989) and (1992); Campos (1994).

19 It is worth adding that we may consider political liberalism in this context even though its view of public justification does not expressly aim to serve the value of emancipation. All we need is that this view sits well with emancipatory commitments. And this it does (on the deep view). I take emancipation to require that real people be accorded a meaningful level of normative influence in matters that affect them. Public justification sits well with this commitment already if it accords to at least some people constitutive discursive standing of high discursive purchase. And, on the deep view, political liberals are (quite profoundly) committed to the view that some people should have this standing — namely, reasonable people. See below and the texts referenced in fn. 17, above.

20 Gaus (1996), p. 130f.

21 Rawls provides his criterion of the reasonableness of disagreement when he writes: "Let's say that reasonable disagreement is disagreement between reasonable persons." (Rawls 2005, p. 55)

22 On the idea of respect that gives rise to political liberalism's idea of public justification: see the seminal Larmore (1990); Larmore (2015), esp. pp. 76-80; Macedo (1991), chapter 2 . 
1 economic institutions, or its domain of the political. And $\varphi$ regulates this they exclusively apply to this domain. But such values must also be part of the political tradition of the society under consideration. And, as Rawls focuses on the United States and its democratic political tradition, he takes it that political values favour liberal democracy.

As to the deep view of public justification, then, it contrasts with a more familiar ideal theory view. On the ideal theory view, public justification is part of ideal theory only, or supposes the context and normative resources of an ideal, wellordered society of the sort prescribed by Rawls's theory of justice, Justice as Fairness (JF). Ideal theory public justification thus includes within its scope only the ideal reasonable citizens of an ideal, well-ordered society. ${ }^{23}$ Now, the deep view of public justification does not deny that Rawls makes use of an idea of ideal theory public justification. But the deep view takes it that Rawls invokes an idea of public justification also for other purposes, outside ideal theory.

Consider Rawls's argument from overlapping consensus. ${ }^{24} \mathrm{He}$ argues that political legitimacy is possible only if political power accords with a conception of justice that can gain an overlapping consensus between the reasonable comprehensive doctrines of reasonable people. This applies also here and now, outside ideal theory. Now, a reasonable overlapping consensus matters for the purposes of legitimacy because a conception of justice, if it is incompatible with any one of the reasonable doctrines that reasonable people endorse, would not be reciprocally acceptable by these people. To ensure a reasonable overlapping consensus just is a way to ensure reciprocal acceptability by the reasonable. Thus, political legitimacy here and now requires reciprocal acceptability by the reasonable here and now. Next, Rawls (notoriously) takes it that a conception of justice can gain an overlapping consensus, or can meet the standard of reciprocal acceptability by the reasonable, only if it avoids reasonable disagreement between reasonable people. Rawls interprets this in populist terms: actual reasonable disagreement about $\varphi$ can count as evidence that $\varphi$ is the subject of reasonable disagreement, and as such is not reciprocally acceptable. Rawls also insists that only a political and liberal conception of justice, if any, avoids reasonable disagreement. And it is for this reasons that he here and now (re)formulates JF as a political liberalism. Taken together, these things suggest that reciprocal acceptability by reasonable people plays a fundamental role. It effectively serves as a standard of theory selection for the domain of the political, as it states a condition any conception of justice (allegedly) must meet in order to be suitable as a basis for a legitimate exercise of political power - and this applies also here and now, outside ideal theory.

23 For a recent form of the ideal theory view, consider Jonathan Quong's version of an internal conception of political liberalism: see Quong (2011).

24 The interpretation of the argument from overlapping consensus used here and below follows Besch (1998), chapter III, and Besch (2004), part I. 
To now bring in discursive respect: as anticipated above, Rawls-type public justification allocates discursive respect that is (i) deep in the order of justification, (ii) rich in discursive purchase, but (iii) notoriously limited in scope. The discursive respect it allocates is deep since the standard of reciprocal acceptability by reasonable people effectively serves as a standard of theory-acceptance for the domain of the political. It is rich in discursive purchase as Rawls interprets this standard in populist terms: at least in some cases, the fact that reasonable people actually reasonably disagree about $\varphi$, given their actual reasonable deliberative resources, counts as evidence that $\varphi$ is not reciprocally, equally acceptable by all reasonable people. As to scope, public justification is highly limited in scope. Only reasonable people are included in its scope on equal, fully enfranchised footing, and hence enjoy full constitutive discursive standing. How limited in scope public justification thereby is depends on how much contested normative content goes into the idea of the reasonable on which public justification builds. As a rule of thumb, the more such content goes into this idea, the more exclusionary public justification will be. Like others, I take it that this idea is rich in contested normative content. Let me indicate why, on the deep view, this often-voiced complaint is justified.

Recall that, for Rawls, political liberalism can avoid reasonable disagreement. Yet the label 'political liberalism' does not refer to just any suitably acceptable conception of justice, but to a conception that (i) is liberal in content, and (ii) constructivist and populist in form of justification, and that (iii) exclusively applies to the domain of the political, and that does so by (iv) containing political values only. As legions of critics have observed, however, there is disagreement about the merits of these requirements. Now, if Rawls construes these disagreements as reasonable, he needs to concede that political liberalism is not reciprocally acceptable by all reasonable people. Yet Rawls does not draw this conclusion. He takes it that only a political liberalism, if anything, is not the subject of reasonable disagreement. Arguably, then, he cannot construe disagreement about (i)-(iv) as reasonable. And this is tantamount to building a commitment to these requirements into the very idea of reasonableness on which public justification builds. ${ }^{25}$ By implication, Rawls needs to suppose,

25 On this reading, what political liberalism defines into its idea of the reasonable - or, as it employs various, systematically and substantively distinct ideas, the idea it treats as politically basic (see Besch 2012 and Besch 1998, chapter IV) - is not a commitment to token political value, token public reasons, or a token political conception of justice. People who are reasonable in political liberalism's sense can coherently disagree about such tokens (provided other conditions are met). What political liberalism defines into reasonableness is a commitment to (i)-(iv) (plus insularity, see below). Thus, reasonableness entails a commitment to a type of values, a type of reasons, and a type of conceptions of justice. Of course, this marks a critical reading of political liberalism's idea of reasonableness. Political liberals disagree with each other as to 
1 as well, that reasonable people accept that reciprocal acceptability by people

2 like them justifies, and that public justification needs to include within its scope only people like them. This makes political liberalism "insular." 26

The upshot: deep public justification here is justification between people who endorse the defining requirements of political liberalism. A commitment to these requirements is part of the doxastic bedrock that public justification supposes, and that everyone included within its scope is expected to share. But, again, in the actual world, outside JF's ideal, well-ordered society of people

9 who are reasonable in political liberalism's sense, there are many relevant people 10 who relevantly contest these requirements and who hence do not pass political 11 liberalism's threshold tests of reasonableness. ${ }^{27}$ This is why the complaint that public justification here is exclusionary is justified. In fact, in light of the above considerations, political liberalism looks like a stretch of public dogma. ${ }^{28}$

\section{Scope-Purchase Interdependence}

What to make of this? Suppose we do not reject that a conception of justice, in order to be able to here and now provide a basis for political legitimacy, must here and now be justifiable in robustly public terms. A standard line of response, then, is to opt for a more inclusive form of robustly public justification - one that builds the standard of reciprocal, equal acceptability on thinner threshold tests of reasonableness, if any, and that hence extends discursive standing of the strong, constitutive kind to more people in moral or political matters that affect them.

how thick in content their respective notions of reasonableness are; Larmore insists that Rawls's notion is much thicker than his own; Macedo insists that Larmore's notion is thicker than Larmore allows; Macedo alone readily concedes that 'reasonableness' is not thin in content. On my reading, their notions are thicker than even Macedo concedes. See Larmore (2015), p. 74; Macedo (1991), p. $260 f$.

26 Estlund (2008), p. 55f.

27 Again, exemplary here: Enoch (2015), p. 121f.

28 Political liberals try to alleviate this problem. For example, Rawls suggests the reasonable address the unreasonable by arguing "from conjecture" (Rawls 2005, p. 465f); Macedo proposes a second stage of public justification that "re-engages" them (Macedo 1991, p. 61ff.), and Larmore suggests (amongst other things) that the reasonable should consider not what the unreasonable actually can or cannot accept, but what they would accept or reject if they were reasonable (Larmore 1996, p. 142). Alas, none of this overcomes the problem: in each case, without due justification, the 'unreasonable' are allocated lesser, second-class discursive standing. See Besch (2012) and (2013). Larmore also offers a contextualist view of (personally) justified belief that would entail that public dogma does not occur as no justification is owed to the unreasonable in the first place. See Larmore (1996), parts I, III; Larmore (2008), pp. 4f, 12; Larmore (2015), p. 71f. Yet this, too, does not overcome the problem: see Besch (2004), part I; Besch (2012). 
At first pass, this seems compelling especially in light of emancipatory and egalitarian intuitions. As Rawls notes, we regard ourselves as "self-authenticating sources of valid claims"29_but not only in relation to the claims we make on institutions in pursuit of conceptions of the good. ${ }^{30}$ We desire to be recognized by others as having an entitlement to make claims on them in relation to what they see as good reasons, at least in matters that affect us. One important part of this recognition is that they regard our non-acceptance of what they see as good reasons as something that can call into question, or put in need of justification, the goodness of these reasons. It may or may not be the case that this desire can be met only if we are being accorded constitutive discursive standing of much purchase. But fully enfranchised inclusion in practices of robustly public justification evidently speaks to this desire. And, if a justification practice allocates this strong standing to anyone, it should allocate it equally to equal people. To say the least, not endorsing political liberalism's defining requirements does not seem to make people relevantly unequal. If anyone is to have discursive standing that is rich in purchase, then not only people who are reasonable in political liberalism's sense should have it.

In what follows, I assume that this line of response is plausible - other things being equal and assuming that a conception of political justice should be robustly publicly justifiable in the actual world, and not only in ideal theory. What I want to do now is to turn to the two problems referred to in the introduction. The first problem reflects the fact that the scope of robustly public justification and the purchase of the discursive standing that such justification can allocate are interdependent. The second problem reflects the complex nature of discursive equality in practices of justificatory reciprocity. Both problems call into question whether a more inclusive form of robustly public justification really can sit well with emancipatory and egalitarian intuitions. I shall now attend to the first problem.

Let me suppose that fully enfranchised discursive inclusion is an important good. Still, we will need to balance this good against other, perhaps no less important goods when it comes into competition with them. And this it does: if discursive respect is rich in purchase, robustly public justification is a mixed blessing. The more inclusive in scope public justification is, the more doctrinal diversity is included in its scope-at least in the real world, outside ideal theory. But the richer in purchase the discursive standing is that each fully enfranchised person enjoys within practices of robustly public justification, the stronger is the normative impact of this diversity on what these practices

29 See Rawls (2001), p. 23.

This is aligned with the views of the earlier Rawls, who sees the self-conception as a self-authenticating source of valid claims as part of people's self-conception as moral (rather than only political) agents: see Rawls (1980), p. $543 \mathrm{f}$. 
1 may count as suitably acceptable, or justifiable. Thus, there is scope-purchase interdependence:

SP Given inclusive scope: the more purchase discursive standing has, the less normative content, such as political principles or value judgements, can qualify as equally acceptable by all relevant others. ${ }^{31}$

For example, suppose liberal political principles must be equally acceptable by relevant citizens, while we read the phrase 'equal acceptability' in high-purchase, coherently be accepted by them in light of their actual views and volitions. Plainly, then, liberal principles - or, by extension of argument, any other, morally interesting normative principles - cannot pass such an actualist threshold if the group of relevant citizens includes people whose moral, political, ethical, or other outlooks are inconsistent with them (and there almost always are such people). The point generalizes: the interdependence of scope and purchase can have problematic implications at any level of argument at which a standard of reciprocal acceptability applies as a standard of justification. It hence can have these implications also in relation to the justification status of the commitment to robustly public justification, or of the view that discursive respect is importantnamely, if these things must be justified by the standard of reciprocal acceptability.

As has often been noted, then, inclusive robustly public justification is at risk of being both self-defeating and unable to secure substantively plausible results ${ }^{32}$ - that is, so long as it accords discursive standing that is rich in purchase. This leaves robustly public justification (RPJ) with several options:

(i) RPJ exempts from the requirement of reciprocal acceptability all normative content that no relevant person should reject (whatever content this is, but assuming it includes values that commit to RPJ and discursive respect).

(ii) RPJ accords high-purchase discursive standing exclusively to people who do not reject normative content that no relevant person should reject.

If robustly public justification accords to people the kind of standing that (ii) refers to, it accords them a standing such that, if they cannot coherently accept $\varphi$ in light of their actual views and volitions (given basic criticality and reasonability), this counts as evidence that $\varphi$ is not suitably acceptable by them. A third option, then, is to reject an actualist notion of discursive standing altogether and to premise robustly public justification on counterfactualizing discursive standing (David Enoch loosely refers to this as a variety of 'idealization'): ${ }^{33}$

31 The idea of a scope-purchase interdependence is developed further in Besch (2014).

32 Exemplary here: Enoch (2015), esp. p. 117 f.

33 Ibid. See also next footnote. 
(iii) In examining $\varphi$ 's public justifiability, RPJ examines whether relevant people can (could, would) suitably accept $\varphi$ provided they do not reject normative content that no relevant person should reject.

For example, suppose we want to protect $\varphi$ from likely opposition, and so decree that $\varphi$ is reciprocally acceptable by people if $\varphi$ is such that relevant people would not reject $\varphi$ if they were reasonable-where reasonableness is then defined in terms that are suitably geared toward the non-rejection of $\varphi$. Thus, if Betty-when-'reasonable' would not reject $\varphi$, then actual Betty's actual inability to coherently accept $\varphi$ would not count as evidence against $\varphi$ 's reciprocal acceptability (rather, it would count as evidence of Betty's unreasonableness).

It is not clear what these three options would amount to in practice. But none seems desirable from an emancipatory and egalitarian point of view. Prior to further argument, the second option abandons the idea of equal discursive respect within inclusive scopes. And prior to further argument, the third option hollows out discursive respect and with it the emancipatory value of robustness in public justification: what worth and use, if any, can Betty's constitutive discursive standing have for her if $\varphi$ counts as 'equally acceptable' by her even if she cannot accept $\varphi$ coherently in light of her actual views and volitions (given basic criticality and reasonability)? Not least, all three options call for an odd kind of government-house public justification: a practice of public justification the terms of which are from the outset tailored to insulate and protect pre-selected moral, political, or other content from likely opposition. And so long as we lack reassurance that this content really is such that no relevant person should reject it - rather than content that, say, reflects the parochial convictions of some dominant group or other-this seems to return us to a variant of public dogma.

The first problem, then, is this. In light of emancipatory and egalitarian intuitions, robustly public justification should allocate to people equal discursive respect that is inclusive in scope and meaningfully rich in purchase. But robustly public justification seems unable to do so while ensuring plausible conclusions and avoiding self-defeat. At any rate, it seems that if such justification must both be inclusive in scope and allocate high-purchase discursive standing, it has to custom-tailor its agenda or abandon its commitment to equal discursive standing. ${ }^{34}$

34 A note on Enoch (2015) is in place. He argues that public reason liberalism-his main target is Rawls-type political liberalism - responds to the presence of unreasonable people by adopting idealization strategies that fail "the test for when idealization is an acceptable philosophical move" (ibid., p. 118) as they are not suitably supported by political liberalism's underlying aims, and specifically the aim to respect the freedom and equality of citizens. Enoch's focus is on two such strategies: the "exclusion" of the unreasonable from public justification, and "going hypothetical," 


\section{Reciprocity and Discursive Purchase}

To now turn to the second problem, let me slightly shift the focus. Justification by a standard of reciprocal acceptability — or justificatory reciprocity, or "reciprocity of reasons" 35 _ seems egalitarian at heart. In requiring reciprocal, equal acceptability of the views it applies to, the standard seems to call for justification practices that accord equal discursive standing to their fully enfranchised participants - even if this standing is being accorded only within limited scopes and with respect to limited agendas. Yet it is not clear in what way this standing really is 'equal.' I will now elaborate on aspects of the issue that have to do with the purchase of discursive standing.

To begin with, two assumptions should be put into place. The first is this: in a justificatory capacity, a standard of reciprocal, equal acceptability cannot require just any kind of equal acceptability. It must require equal authoritative acceptability. For example, equally incoherent, ill-informed, or unreasonable acceptance cannot positively contribute to the justification status of a view (or its validity, correctness, or reasonableness), nor can similarly deficient rejections negatively contribute to it. The need for authoritativeness constraints complicates matters. For it entails that the question of whether some view, $\varphi$, is equally acceptable by relevant people must be crossed with considerations

which roughly is a species of option (iii), above (ibid., 120-130). Yet, insofar as he targets Rawls-type political liberalism, Enoch's criticism misfires. True, political liberalism does not include the unreasonable on fully enfranchised footing within the scope of public justification. And, yes, it goes hypothetical at least in relation to the unreasonable. For example, Larmore stresses that political liberalism considers the interests or views of the unreasonable by imagining what they would accept or reject if they were reasonable (Larmore 1996, p. 142). But this is supported by political liberalism's aims. For, from the outset, political liberalism aims to respect as free and equal not all citizens, but only reasonable people. And, from the outset, it fully includes in public justification only people it respects as free and equal, i.e., reasonable people. As Macedo puts it, political liberals "respect as free and equal moral beings all those who pass certain threshold tests of reasonableness: we respect those whose disagreement with us does not impugn their reasonableness" (Macedo 1991, p. 47). Thus, political liberals do not aim to equally include the unreasonable to begin with. Note that this does not commit them to an ideal theory view of public justification. Instead, they can adopt the deep view of public justification (see above). Enoch's objection hence builds on an inadequate reading of public reason liberalism. The problem is not that political liberalism deploys idealizations that are not supported by its underlying aims. Rather, the problem is that it is vulnerable to a charge of public dogma - while attempts to fix this problem while keeping a commitment to robustly public justification in place seem to run into the difficulties discussed above. 35 See Forst (2010), p. 719. 
as to whether meeting the underlying authoritativeness constraint is suitably available to them. (Given my present context, I shall often put things in terms of a reasonableness threshold.)

A second, initially plausible assumption is this: the 'equal' discursive standing that practices of justificatory reciprocity allocate should be equal not just in some abstract sense, but concretely in terms of its discursive purchase. Consider a justification practice, JP1, that allocates to Betty and Paul constitutive discursive standing, and hence discursive standing of the same abstract kind, but applies to them different thresholds of authoritativeness such that their discursive standing has unequal purchase. Say, Paul enjoys actualist discursive respect such that, if Paul cannot accept $\varphi$ in light of his actual views and volitions, the practice recognizes this as counting against $\varphi$, or as showing that $\varphi$ fails to be suitably acceptable by Paul. Yet Betty is being accorded counterfactualizing discursive respect such that, if she cannot accept $\varphi$ in light of her actual views and volitions, this is not recognized as counting against $\varphi$, but as counting against her-say, it is counted as evidence that she is insufficiently reasonable, rational, right-minded, and so forth. Surely, this would instantiate relevant discursive inequality: Paul has a veto, but Betty does not. Their discursive standing is equal in abstract kind, and so is up to a point equal, but it is relevantly unequal in purchase. (We shall see below that this assumption, despite its appeal, is problematic.)

These two assumptions suggest that the standard of justificatory reciprocity calls for justification practices that do two things (amongst many others): they apply authoritativeness constraints — or, given my focus: some reasonableness threshold - to the members of their constituency, or their deliberative behaviour, while simultaneously according them discursive standing of equal discursive purchase. However, real-life justification practices may not be able to do both, or be known to do both.

Consider another justification practice, JP2, that adopts a counterfactualizing conception of discursive respect and applies it consistently to all participants: say, one that defines deliberations, objections, acceptances, rejections, and so on, as authoritative, or as counting toward the justification status of views, only to the extent that they are reasonable - while it construes reasonableness in normatively demanding terms. And suppose that these terms are demanding enough to make it relevantly harder for some participants than others to count as 'reasonable' —or to register 'reasonable' objections, rejections, acceptances, and so forth. Say, Outstanding Betty meets these terms with ease so that her voice usually counts as reasonable anyway, while Limited Paul, given his limited deliberative resources, does not meet them with ease so that his voice usually counts as reasonable only after his views and volitions have undergone (sometimes even considerable) second guessing, filtering, laundering, or revisions. I take it that Betty and Paul here have standing of unequal purchase. But this purchase differential is now not owed to the fact that actualist discursive respect is applied to one but not the other. It is owed to the fact that Betty and 
1 Paul bring different resources to the task: given her superior resources, Betty 2 qualifies as more 'reasonable' than Paul.

The contrast between JP1 and JP2 suggests a distinction between formal and substantive equality of discursive standing. Let me take it that a justification practice accords to relevant people discursive standing that is formally 6 equal only if (i) it accords them discursive standing of the same abstract type 7 (e.g., constitutive discursive standing), and (ii) applies to each the same 8 threshold of authoritative acceptability. A justification practice accords to people discursive standing that is substantively equal, however, only if their respective discursive standing has equal discursive purchase. Thus, JP1 seems further removed from the egalitarian commitments of justificatory reciprocity than JP2: JP1 accords to Betty and Paul discursive standing of the same abstract kind, but that standing is neither formally nor substantively equal. By contrast, JP2 accords them discursive standing that is formally equal, although it is not also substantively equal.

Alas, purchase differentials that result from resource differentials are unavoidable in any form of larger-scale real-life public justification. Who counts as an Outstanding Betty or a Limited Paul in a given practice of public justification depends on how the practice defines reasonableness (assuming it adopts some reasonableness threshold), but it also depends on what deliberative resources people bring to the task of public reasoning. And there always are differences between our deliberative resources - or whatever capacities, skills, commitments, attitudes, views, volitions, and so on, our practical reasoning draws on. People's deliberative resources are unlikely to fall below some baseline that comes with intelligent agency. But it is equally plain that their resources often vary greatly in ways that affect how readily available it is for them to count as 'reasonable' - especially when 'reasonableness' is taken to require not just basic criticality and reasonability, but, say, substantive commitments not everyone shares anyway. And we usually do not know just how readily available this is for them at least when distant strangers are concerned - if only because we do not know just what their deliberative resources are. Thus: if the standard of justificatory reciprocity calls for justification practices that allocate substantively equal discursive standing, we would not know when our attempts at justificatory reciprocity succeed where large and diverse, society-scale groups are concerned. But such just are the constituencies of the standard in its alleged main role as a standard of moral or political justification. If the standard is to be a serious candidate for this role, then something must give way.

This point is less trivial than it might seem at first sight. It suggests we reject a maximalist conception of justificatory reciprocity—call it 'deep reciprocity':

DR $\varphi$ is acceptable equally (or reciprocally) by Betty and Paul if and only if (i) Betty and Paul can each accept $\varphi$ reasonably and (ii) meeting the threshold of reasonableness is an option equally available to both, given their actual deliberative resources. 
1 Deep reciprocity requires not simply that justification practices allocate discur2 sive standing that is equal in some purchase-sensitive way. Rather, it requires 3 substantive equality. This may have intuitive appeal. As we have just seen, 4 however, it would push justificatory reciprocity out of its alleged main role. 5 As we do not know with relevant specificity what the deliberative resources 6 of relevant people are, we would rarely, if ever, be able to tell whether a given 7 reasonableness threshold is suitably available by all relevant people. In the 8 world as we know it, then, we have reasons to set aside DR.

We should not fall into the opposite extreme and opt for a purchase-insensitive, minimalist conception of justificatory reciprocity—call it 'nominal reciprocity':

NR $\varphi$ is acceptable equally (or reciprocally) by Betty and Paul if and only if Betty and Paul can each accept $\varphi$ reasonably.

Nominal reciprocity is consistent with objectionable forms of discursive inequality. Consider a justification practice, JP3, which accords to all relevant people discursive standing of the same abstract type and applies to all relevant people the same reasonableness threshold. But JP3 defines that threshold in terms that give trumping weight to moral conceptions, $\mathrm{C}$, that members of Dominant Group typically endorse, and members of Marginal Group typically reject. Say, JP3 counts acceptances, or rejections, as authoritative, or reasonable, only if they cohere with C. JP3 instantiates formal equality. Yet this would merely mask that JP3 gives full discursive standing only to members of Dominant Group - thus cementing their dominating influence at the level of practices of reason giving. It hence seems that NR would not provide a plausible conception of justificatory reciprocity.

If NR is unsuitable, a more familiar conception of justificatory reciprocity is not quite suitable either - call it 'strong reciprocity':

SR $\varphi$ is acceptable equally (or reciprocally) by Betty and Paul if and only if (i) Betty and Paul can each accept $\varphi$ reasonably, given (ii) a threshold of reasonableness that is equally acceptable by them. ${ }^{36}$

Strong reciprocity leads us back to the problem of nominal reciprocity, albeit at a deeper level of thought. For when are reasonableness thresholds equally acceptable by Betty and Paul? Surely, what matters is not their equal brute acceptability, but their equal authoritative acceptability. Yet that Betty and Paul can accept some reasonableness threshold 'authoritatively' does not mean that this is an option equally open to both. Thus, SR, too, can mask relevant discursive inequality.

36 This is akin to Bruce W. Brower's view of public reasoning as reasoning by a standard of equal rational acceptability given a standard of rationality that is ‘equally acceptable' by all relevant others. See Brower (1994). 
The second challenge, then, is to specify the nature of discursive equality in justificatory reciprocity in a way that maintains purchase-sensitivity, but that does not push the standard of justificatory reciprocity out of its alleged main role. The above suggests that a conception of justificatory reciprocity must be located in the normative space between deep reciprocity and nominal reciprocity. If purchasesensitivity matters - as it seems to, not least given emancipatory intuitions - we should reject purchase-insensitive conceptions of justificatory reciprocity such as nominal reciprocity and with it, I suggested, strong reciprocity. However, purchase9 sensitivity cannot take the maximalist form of deep reciprocity. The standard of justificatory reciprocity is a viable candidate for the role of a standard of robustly public justification only if either (i) it does not after all require discursive standing to be equal, or (ii) discursive standing can count as equal even when it is unequal in purchase. This is an uneasy result. If we set aside (i) - given egalitarian intuitions - then if equal discursive standing is not (also) a matter of discursive standing that is equal in purchase, what is it a matter of? How much purchase inequality is compatible with justificatory reciprocity? How much is permissible, or justifiable? The target of these questions is not the importance of discursive equality, but the view that justificatory reciprocity is a natural ally of egalitarianism at the level of discursive inclusion. For it is not clear what kind of discursive equality, if any, justificatory reciprocity can require. ${ }^{37}$

Let me add one more point. One manoeuver that is possible here surfaced earlier: we might index the purchase of an agent's discursive standing not to

37 As an anonymous reviewer notes, purchase differentials that arise through differences in deliberative resources might sometimes be permissible. In fact, some must be permissible if discursive equality is purchase sensitive and a standard of justificatory reciprocity is to be a serious candidate for the role of a standard of justification. When are purchase inequalities permissible? It is hard to tell: many initially plausible, but potentially conflicting, permissibility constraints are conceivable. To sample just two, consider a justification practice, JP4, which sets its bar for authoritativeness $\psi$ such that it counts discursive input about a given subject matter, $\mathrm{S}$, as authoritative only if this input demonstrates special expertise about S. Now consider Best Results (BR): purchase inequalities that arise from JP's adoption of $\psi$ are permissible only if JP is more likely to recognize discursive input as authoritative that JP should recognize as such when it adopts $\psi$, than when it does not adopt $\psi$ (as assessed on JP-independent grounds). In light of BR, at least some of JP4's purchase differentials might be permissible. Yet factor in that JP4's participants might relate to each other in ways that constitute relevant recognitive improprieties, e.g., social biases, identity prejudices, or Fricker-type hermeneutic injustices, widely conceived so as to not be limited to epistemic, strictly truth-related pursuits (see Fricker 2007, esp. pp. 152-169). Thus, take Impropriety Prohibited (IP): purchase differentials within JP are permissible only if they do not result from recognitive impropriety (as defined by a JP-independent standard). IP might prohibit the very purchase differentials that BR permits if, say, 
1 the actual deliberative resources of that actual agent, but construe purchase in 2 idealized or normalized terms. For example, we might index it to the recourses 3 that the agent should have, or would have after relevant improvement; or to 4 ideal resources of ideal agents; or to average resources or minimal resources5 amongst other possibilities. Purchase may need to be construed in such terms 6 if we want to maintain (i) that the standard of justificatory reciprocity is viable as a standard of public justification and (ii) that the standard in that role calls for discursive standing that is equal in purchase. After all, idealization and normalization enable us to identify discursive standing as 'equal' in purchase even when it is relevantly unequal in actual purchase. However, this is a spurious achievement. If discursive standing that is equal in idealized or normalized purchase can be relevantly unequal in real purchase, equality of idealized or normalized purchase can still mask relevant discursive inequality. And so the question still is how much (actual) purchase inequality is compatible with justificatory reciprocity, and how much is permissible or justifiable.

\section{Conclusion}

To conclude, there can be different conceptions of justificatory reciprocity, depending on how we calibrate the standard of reciprocal acceptability, or the discursive respect it allocates, in the dimensions of depth, scope, and purchase. Political liberalism's variant of justificatory reciprocity has high values in the dimensions of depth and purchase, but an implausibly low value in the dimension of scope. For political liberalism, robustly public justification fully enfranchises reasonable people only, while people count as reasonable only if they share political liberalism's defining commitments. This invites the charge of public dogma.

One response to this is to opt for a more inclusive form of robustly public justification. I drew out two problems that an inclusive conception of robustly public justification faces. On the one hand, it needs to calibrate robustly public justification in the above dimensions in such a way that it is plausibly inclusive in scope and rich in discursive standing, while ensuring plausible conclusions and avoiding self-defeat — without public dogma. On the other hand, it needs

it relevantly misrecognizes some JP4-relevant people to discount their discursive input just because it does not instantiate whatever BR defines as 'special expertise.' As this illustrates, there can be, and are, many competing considerations that bear on the permissibility of purchase inequality. It is open how best to systematize them; and it is open what permissibility constraints on purchase inequality we should adopt. A more systematic treatment of the matter calls for an ethic of discursive purchasewhich is beyond the scope of my current discussion. At any rate: once we construe of justificatory reciprocity in non-ideal terms and accept that discursive equality is purchase sensitive, questions about the permissibility of purchase inequality multiplybringing this out was part of the point of this section. 
1 to conceptualize discursive equality in purchase-sensitive terms without 2 pushing the standard of justificatory reciprocity out of its alleged main role. 3 Both problems go to the heart of justificatory reciprocity, or its normative 4 grammar. And both are difficult to overcome. If there are no widely shareable 5 ways to overcome them, there is no form of robustly public justification that 6 we can with good confidence claim to be inclusive, non-dogmatic, and eman7 cipatory and egalitarian in the right way.

\section{Acknowledgements:}

For discussions on earlier versions of this paper or ideas included here, I am indebted to Paul Patton, Ben Cross, Jung-Sook Lee, attendees of presentations at the University of New South Wales and Wuhan University, as well as various student groups at Wuhan University.

\section{References}

Arneson, Richard

2004 "Democracy is Not Intrinsically Just." In Justice and Democracy, eds.

K. Dowding, R.E. Goodin, C. Pateman, Cambridge: Cambridge University Press, $40-58$.

Besch, Thomas M.

1998 Über John Rawls's politischen Liberalismus. Frankfurt: Peter Lang.

Besch, Thomas M.

2004 On Practical Constructivism and Reasonableness. PhD diss., University of Oxford.

Besch, Thomas M.

2012 "Political Liberalism, the Internal Conception, and the Problem of Public Dogma." Philosophy and Public Issues (New Series) 2 (1): 153-177.

Besch, Thomas M.

2013 “On Political Legitimacy, Reasonableness, and Perfectionism.” Public Reason 5 (1): 58-74.

Besch, Thomas M.

2014 “On Discursive Respect." Social Theory and Practice 40 (2): 207-231.

Besch, Thomas M.

2017a "On justification, idealization, and discursive respect." Manuscript. Available at: https://www.academia.edu/33343942/On justification idealization_and_discursive_purchase.

Besch, Thomas M.

2017b "Political liberalism and public justification: the deep view." Manuscript. Available at: https://www.academia.edu/25694168/Political_liberalism_

Brower, Bruce W. and_public_justification_the_deep_view.

1994 “The Limits of Public Reason.” Journal of Philosophy 91 (1): 5-26.

Campos, Paul F.

1994 “Secular Fundamentalism” Columbia Law Review 94 (6): 1814-1827. 
Enoch, David

2015

“Against Public Reason.” In Oxford Studies in Political Philosophy, Vol.1, eds. D. Sobel, P. Vallentyne, S. Wall, Oxford: Oxford University Press, 112-144.

Estlund, David

2008

Forst, Rainer

2010 "The Justification of Human Rights and the Basic Right to Justification: A Reflexive Approach." Ethics 120 (4): 711-740.

Forst, Rainer

2011 "The Ground of Critique: On the Concept of Human Dignity in Social Orders of Justification." Philosophy and Social Criticism 37 (9): 965-976.

Forst, Rainer

2012 The Right to Justification. New York: Columbia University Press.

Forst, Rainer

2015a “Noumenal Power.” Journal of Political Philosophy 23 (2): 111-127.

Forst, Rainer

2015b "A critical theory of politics: Grounds, method and aims. Reply to Simone Chambers, Stephen White and Lea Ypi." Philosophy and Social Criticism 41 (3): 225-234.

Fricker, Miranda

2007 Epistemic Injustice. Oxford: Oxford University Press.

Gaus, Gerald

1996 Justificatory Liberalism. Oxford: Oxford University Press.

Hampton, Jean

1989 "Should Political Philosophy Be Done Without Metaphysics?" Ethics 99 (4): 791-814.

Hampton, Jean

1992 "The Moral Commitments of Liberalism.” In The Idea of Democracy, eds. D. Copp, J. Hampton, J.R. Roemer, Cambridge: Cambridge University Press, 292-313.

Larmore, Charles

1990 "Political Liberalism.” Political Theory 18 (3): 339-360.

Larmore, Charles

1996 The Morals of Modernity. Cambridge: Cambridge University Press.

Larmore, Charles

2008 The Autonomy of Morality. Cambridge: Cambridge University Press.

Larmore, Charles

2015 "Political Liberalism. Its Motivation and Goals." In Oxford Studies in Political Philosophy, Vol. 1, eds. D. Sobel, P. Vallentyne, S. Wall, Oxford: Oxford University Press, 63-87.

Macedo, Stephen

1991 Liberal Virtues. Oxford: Clarendon Press. 


\section{Dialogue}

Nagel, Thomas

1991 Equality and Partiality. Oxford: Oxford University Press.

O’Neill, Onora

1988 "Ethical Reasoning and Ideological Pluralism.” Ethics 98 (4): 705-722.

O’Neill, Onora

1996 Toward Justice and Virtue. Cambridge: Cambridge University Press.

O’Neill, Onora

2000 Bounds of Justice. Cambridge: Cambridge University Press.

\section{Postema, Gerald J.}

1995a "Public Practical Reasoning: An Archeology." Social Philosophy and Policy 12 (1): 43-86.

\section{Postema, Gerald J.}

1995b "Public Practical Reason: Political Practice." In Theory and Practice, eds. I. Shapiro, J.W. DeCew, New York: New York University Press, 345-385.

Quong, Jonathan Quong

2011 Liberalism without Perfection. Oxford: Oxford University Press.

Rawls, John

1980 "Kantian Constructivism in Moral Theory." Journal of Philosophy 7 (9): 515-577.

Rawls, John

2001 Justice as Fairness: A Restatement. Edited by Erin Kelly. Cambridge (MA): Belknap Press.

Rawls, John

2005 Political Liberalism. New York: Columbia University Press.

Ronzoni, Miriam

2010 "Constructivism and Practical Reason: On Intersubjectivity, Abstraction, and Judgment.” Journal of Moral Philosophy 7 (1): 74-104.

Steinhoff, Uwe

2015 "Against Equal Respect and Concern, Equal Rights, and Egalitarian Impartiality." In Do All Persons Have Equal Moral Worth?, ed. U. Steinhoff, Oxford: Oxford University Press, 142-172.

Vallier, Kevin

2011 “Against Public Reason Liberalism's Accessibility Requirement." Journal of Moral Philosophy 8 (3): 366-389.

Vallier, Kevin

2015a "Public justification versus public deliberation: the case for divorce." Canadian Journal of Philosophy 45 (2): 139-158.

Vallier, Kevin

2015b "In Defence of Intelligible Reasons in Public Justification." Philosophical Quarterly 66 (264): 596-616.

Wall, Steven

2016 “The Pure Theory of Public Justification.” Social Philosophy and Policy 32 (2): 204-226. 


\section{AUTHOR QUERIES}

QA $\quad$ The distinction between surnames can be ambiguous, therefore to ensure accurate tagging for indexing purposes online (eg for PubMed entries), please check that the highlighted surnames have been correctly identified, that all names are in the correct order and spelt correctly. 